\title{
Faktor-Faktor Ambisi Politik Imigran Korea Utara di Korea Selatan (Studi Kasus: Keterlibatan Thae Yong-Ho dan Ji Seong-Ho sebagai Kandidat dalam Kontestasi Pemilu Legislatif di Korea Selatan Tahun 2020)
}

\author{
Ega Eugenia Naomi ${ }^{1 *}$, Ali Muhyidin ${ }^{1}$
}

${ }^{1}$ Universitas Indonesia, Indonesia

\author{
A R T I C L E I N F O \\ Article history: \\ Received 17 Maret 2021 \\ Accepted 17 Mei 2021 \\ Available online 30 Juni \\ 2021 \\ Kata Kunci: \\ Pemilu; Expressive \\ Ambition; Imigran; Korea \\ Utara; Korea Selatan; \\ Nascent Ambition \\ Keywords: \\ Election; Expressive \\ Ambition; Immigrant; \\ North Korea; South Korea; \\ Nascent Ambition
}

\begin{abstract}
A B S T R A K
Artikel ini membahas tentang bagaimana imigran asal Korea Utara terlibat dalam kontestasi di Pemilihan Legislatif tahun 2020 di Korea Selatan. Dengan menggunakan metode penelitian kualitatif dan teknik studi literatur, penelitian ini menjelaskan faktor-faktor apa saja yang mendorong ambisi politik Thae Yong-ho dan Ji Seong-ho. Temuan penelitian ini menunjukkan bahwa ambisi politik kedua tokoh tersebut muncul didorong oleh berbagai faktor personal yaitu sosialisasi politik, pengalaman profesional individu, rekrutment politik, serta isu dan sikap politik terhadap kebijakan luar negeri Presiden Moon Jae-in mengenai hubungan Korea Selatan dan Korea Utara. Identifikasi faktor pendorong ambisi politik individu tidak hanya penting untuk menjawab pertanyaan mengapa individu berkompetisi pemilu, namun juga bagaimana ambisi personal berkembang sejalan dengan strukur kesempatan politik. Hasil penelitian ini diharapkan dapat menambah perspektif terkait kebijakan politik di negara demokrasi dalam merespon isu imigran.
\end{abstract}

\section{A B S T R A C T}

This article discusses how North Korean immigrants were involved in contesting the 2020 Legislative Elections in South Korea. Using qualitative research methods, this study explains what factors drive Thae Yong-ho and Ji Seong-ho's political ambitions. We find that the two figures' political ambitions emerged driven by various personal factors, namely political socialization, individual professional experience, political issues, political recruitments, and attitudes towards President Moon Jae-in's foreign policy regarding South and North Korea. Identifying individual political ambition drivers is essential in answering why individuals run to compete in an election and how personal ambition develops along with its political opportunity structures. We expect to add more perspectives in democratic countries in responding to the issue of immigrants. 


\section{Pendahuluan}

Sebagai negara dengan tingkat demokrasi yang maju, Korea Selatan tentunya tidak lepas dari permasalahan imigran. Isu imigran di Korea Selatan sendiri dapat diklasifikasikan menjadi dua kategori, yaitu imigran global dan pembelot Korea Utara. Pada tahun 2001, Korea Selatan mulai menerima imigran asing yang mengalami krisis di negaranya. Akan tetapi, masalah imigran global bagi Seoul sendiri kurang diprioritaskan, sehingga tingkat penerimaan imigran di negara tersebut masih tergolong sangat rendah dibandingkan dengan negara-negara anggota Organization for Economic Cooperation and Development (OECD) lainnya (Lee, 2019). Di sisi lain, Pemerintah Korea Selatan lebih menyambut imigran asal Korea Utara yang melarikan diri ke negara tersebut dengan mengeluarkan kebijakan-kebijakan yang menyejahterakan orang-orang Korea Utara di Korea Selatan, seperti Settlement Support di Hanawon yang turut berupaya mengonstruksikan nilai-nilai di lingkungan Korea Selatan, pelatihan kerja, serta bantuan finansial juga diberikan kepada imigran Korut. Dalam sejarahnya, Korea Utara pernah mengalami krisis ekonomi dan politik pada tahun 1990-an yang menyebabkan ribuan warga Korea Utara meninggalkan negara mereka akibat penindasan politik dan keputus-asaan ekonomi yang mereka rasakan. Salah satu destinasi pelarian mereka adalah Korea Selatan karena masih adanya ikatan sejarah dan etnis yang kuat, serta bahasa yang mirip membuat mereka berekspetasi akan jauh lebih mudah diterima di sana. Hingga tahun 2020, tercatat sebanyak 33.670 penduduk Korea Utara telah bermigrasi ke Korea Selatan berdasarkan data dari Kementerian Unifikasi Korea Selatan.

Di Korea Selatan, para imigran Korea Utara ini mulai menjangkau spektrum politik dan ideologi di negara tersebut (Chubb, 2010). Memang aktivitas politik yang dilakukan oleh kelompok imigran Korea Utara sejak dulu cenderung bersifat informal, seperti membentuk komunitas mereka sendiri yang berperan penting dalam mengadvokasi masalah hak asasi manusia di Korea Utara dengan konteks yang lebih luas hingga menjangkau transnasional. Mereka juga membentuk lembaga swadaya masyarakat (LSM) yang mulanya bertujuan untuk "mengedukasi" masyarakat Korea Selatan tentang masalah hak asasi manusia di Korea Selatan. Namun, seiring berjalannya waktu, tujuan LSM ini mulai bergeser untuk mempengaruhi pembuatan kebijakan luar negeri Korea Selatan terhadap Korea Utara secara langsung. Hal ini tentu saja mendapat perhatian yang semakin besar di publik Korea Selatan, seperti LSM, gereja, akademisi, dan lembaga think tank. Sejalan dengan pernyataan Huddleston (2017), penulis berargumen bahwa sebagian imigran Korea Utara di Korea Selatan masih kerap dianggap pasif dan apolitis karena (i) mereka lebih suka berpartisipasi dengan cara yang kurang konvensional, seperti terlibat dalam LSM-LSM yang menaungi masalah hak asasi manusia di Korea Utara dibandingkan terlibat langsung dalam proses politik di Korea Selatan, (ii) mereka juga tidak dimobilisasi untuk menuntut hak politik konvensional, dan (iii) mereka berasal dari negara Korea Utara yang tentunya terkenal dengan tingkat demokratisasi dan partisipasi warga negara yang rendah.

Namun, ketiga alasan tersebut sebenarnya tidak menutup kemungkinan adanya para imigran yang kemudian aktif dalam ranah formal (konvensional), seperti terjun langsung ke dunia politik praktis dan memiliki akses untuk masuk ke dalam partai politik. Rupanya, aktivitas politik para pembelot Korea Utara ini semakin terlihat jelas dengan munculnya tokoh-tokoh aktivis, seperti Thae Yong-ho dan Ji Seong-ho, yang ikut mencalonkan diri dalam kontestasi Pemilihan Legislatif di Korea Selatan tahun 2020. Meskipun hasil pemilu menunjukkan kemenangan telak koalisi partai progresif petahana Presiden Moon Jae-in, namun cukup mengejutkan bahwa kedua kandidat asal Korea Utara ini berhasil memenangkan bangku parlemen di pemilihan legislatif tersebut melalui dukungan partai konservatif di Korea Selatan. Keterlibatan imigran Korea Utara di dalam politik elektoral Korea Selatan menjadi suatu hal yang menarik untuk dibahas lebih mendalam.

Penelitian ini bertujuan untuk membahas faktor-faktor apa saja yang mendorong ambisi politik Thae Yong-ho dan Ji Seong-ho sebagai imigran Korea Utara untuk mencalonkan diri menjadi kandidat di dalam Pemilu Legislatif Korea Selatan 2020. Studi mengenai ambisi politik imigran untuk mencalonkan diri ke dalam politik elektoral di negara tujuannya sebenarnya sudah 
cukup beragam. Salah satu studi imigran di Swedia memperlihatkan bahwa sebenarnya kelompok imigran cukup tertarik dengan masalah politik seperti penduduk asli kebanyakan. Imigran di Swedia juga tertarik untuk mencalonkan diri ke dalam politik elektoral, tetapi keinginan mereka digagalkan oleh elite politik yang merusak kesempatan mereka untuk memegang sebuah jabatan politik (Dancygier et. Al, 2020). Sementara, studi imigran di Amerika Serikat menyebutkan adanya akses struktural politik yang seimbang antara imigran dengan non-imigran, tetapi imigran cenderung sulit untuk terlibat di dalam politik elektoral dikarenakan minimnya sumber daya yang dimiliki, seperti kurangnya pengalaman profesional dan politik, serta masalah finansial yang berkontribusi pada rendahnya kualifikasi imigran. Sekalipun ada imigran yang terlibat aktif di politik dan memiliki posisi yang baik untuk mencalonkan diri, namun mereka kerap mengalami hambatan psikologis yang disebabkan oleh adanya perbedaan ras, etnis, identitas imigran, status kewarganegaraan, kemampuan berbahasa, dan kesulitan berakulturasi (Reny \& Shah, 2018).

Penelitian mengenai ambisi politik dan faktor-faktor yang memotivasi imigran Korea Utara untuk mencalonkan diri sebagai kandidat dalam politik elektoral di Korea Selatan masih sangat terbatas (Jeong, H. O., \& Kim, Y. S., 2016). Penelitian ini diharapkan dapat berkontribusi dalam mengidentifikasi faktor pendorong ambisi politik individu untuk berkompetisi pemilu dan juga bagaimana ambisi personal berkembang dan teraktualiasasi dalam konteks politik di negara demokrasi.

\section{Metode}

Penelitian ini merupakan penelitian kualitatif dengan menggunakan pendekatan studi kasus sebagai strategi penelitian yang menekankan peneliti untuk mengeksplorasi secara mendalam suatu peristiwa, aktivitas, proses, dan/atau individu atau lebih (Creswell, 2007: 16). Penelitian ini berfokus pada tahun 2020 yang mengangkat peristiwa atas keterlibatan dan kemenangan dua kandidat asal Korea Utara dalam Pemilu Legislatif di Korea Selatan sebagai bentuk partisipasi politik imigran. Teknik pengumpulan data yang digunakan dalam penelitian ini menggunakan studi literatur dan dokumentasi untuk mendapatkan data-data sekunder. Creswell (2007) menjelaskan bahwa studi literatur digunakan untuk mengambil data-data tertulis. Oleh sebab itu, dalam penelitian ini, penulis menggunakan data-data yang ditemukan dalam bentuk berita, jurnal/penelitian terdahulu, transkrip wawancara, video rekaman wawancara, dan data publik yang ada. Dalam hal ini, penulis akan lebih banyak menggunakan sumber berita online sebagai data penunjang informasi tambahan. Penelitian ini juga menggunakan teknik analisis kualitatif yang menekankan intepretasi penulis atas data yang ditemukan.

\section{Hasil dan pembahasan}

Thae Yong-ho adalah seorang mantan wakil duta besar Korea Utara di Inggris, sekaligus salah satu pejabat tertinggi di Korea Utara. Namun, pada tahun 2016, ia memilih untuk melepaskan jabatannya yang prestisius tersebut dan membelot ke Korea Selatan bersama dengan istri dan anak-anaknya. Sementara itu, Ji Seong-ho adalah salah satu pembelot Korea Utara yang bernasib terbalik dari hidup Thae Yong-ho sendiri. Berdasarkan cerita hidupnya, ia merupakan salah satu warga negara Korea Utara yang ikut mengalami masa The Great Famine pada tahun 1996. Serupa dengan kisah para pembelot Korea Utara kebanyakan, ia akhirnya memilih untuk melarikan diri dari negara tersebut bersama saudaranya pada tahun 2006 melalui Sungai Tumen ke Cina, kemudian melanjutkan perjalanan melewati Laos dan Thailand, hingga akhirnya bisa mencapai Korea Selatan (Fifield, 2018). Pada Pemilihan Legislatif Korea Selatan tahun 2020 silam, keduanya menempati posisi sebagai kandidat dari Korea Utara yang turut berkontestasi dalam memperebutkan bangku parlemen di Korea Selatan.

Keterlibatan kedua imigran asal Korea Utara ini tentu tidak bisa lepas dari ambisi politik yang dimiliki keduanya. Ambisi politik dapat didefinisikan sebagai sebuah keinginan untuk mendapatkan dan mempertahankan kekuasaan politik melalui cara elektoral (dalam LeRoux \& Langer, 2019). Premis sentral dari ambisi politik melekat pada karakteristik dan atribut tetap yang dimiliki indvidu, serta adanya struktur politik yang memberikan peluang, seperti jumlah kursi yang tersedia, komposisi partisan di daerah pemilihan, hingga kesesuaian partai politik 
dengan konstituennya dapat menjadi faktor-faktor yang mendorong keterlibatan seseorang dalam politik elektoral. Pada mulanya, para ilmuwan politik menyebut struktur peluang politik sebagai expressive ambition yang mendorong terbentuknya pilihan ambisi politik individu, berupa (i) ambisi progresif, yaitu adanya keinginan untuk mencalonkan diri ke jabatan yang lebih tinggi, (ii) ambisi statis, yaitu keinginan bagi para pejabat untuk mempertahankan posisi mereka, (iii) ambisi diskrit, yaitu pilihan bagi individu untuk mengundurkan diri atau berhenti dibandingkan mengikuti pemilihan lagi.

Kemudian, Jennifer Lawless dan Richard Fox (2005) mengemukakan bahwa ambisi politik lebih dari sekadar struktur peluang politik. Mereka menyadari bahwa jika gagasan tentang pencalonan tidak pernah terlintas di benak seseorang, maka tentunya ia tidak akan pernah benarbenar menghadapi struktur peluang politik itu sendiri. Bagi Lawless dan Fox, minat individu untuk mendapatkan jabatan kemungkinan besar dimotivasi bukan oleh struktur peluang politik saja, melainkan disposisi sikap dan pengalaman pribadi yang memfasilitasi atau menghalangi kemungkinan individu untuk mencalonkan diri. Oleh sebab itu, keduanya mencetuskan adanya ambisi yang baru lahir (nascent ambition) atau kecenderungan baru bagi individu untuk mempertimbangkan dirinya terlibat di dalam pencalonan. Faktor-faktor strategis nascent ambition ini berfungsi sebagai pendahulu kritis untuk mencapai expressive ambition terkait. Sehingga, konsepsi mengenai ambisi politik ini dipahami sebagai sebuah fenomena yang didorong oleh struktur peluang politik yang harus dihadapi oleh kandidat potensial. Namun, untuk masuk ke dalam struktur tersebut, individu tentunya memiliki kecenderungan untuk mempertimbangkan pencalonan. Pada akhirnya, Lawless (2012) mengemukakan faktor-faktor yang dianggap membentuk nascent ambition calon kandidat, dapat berupa faktor sosialisasi politik, pengalaman profesional, serta isu politik, sikap politik, dan rekruitmen politik.

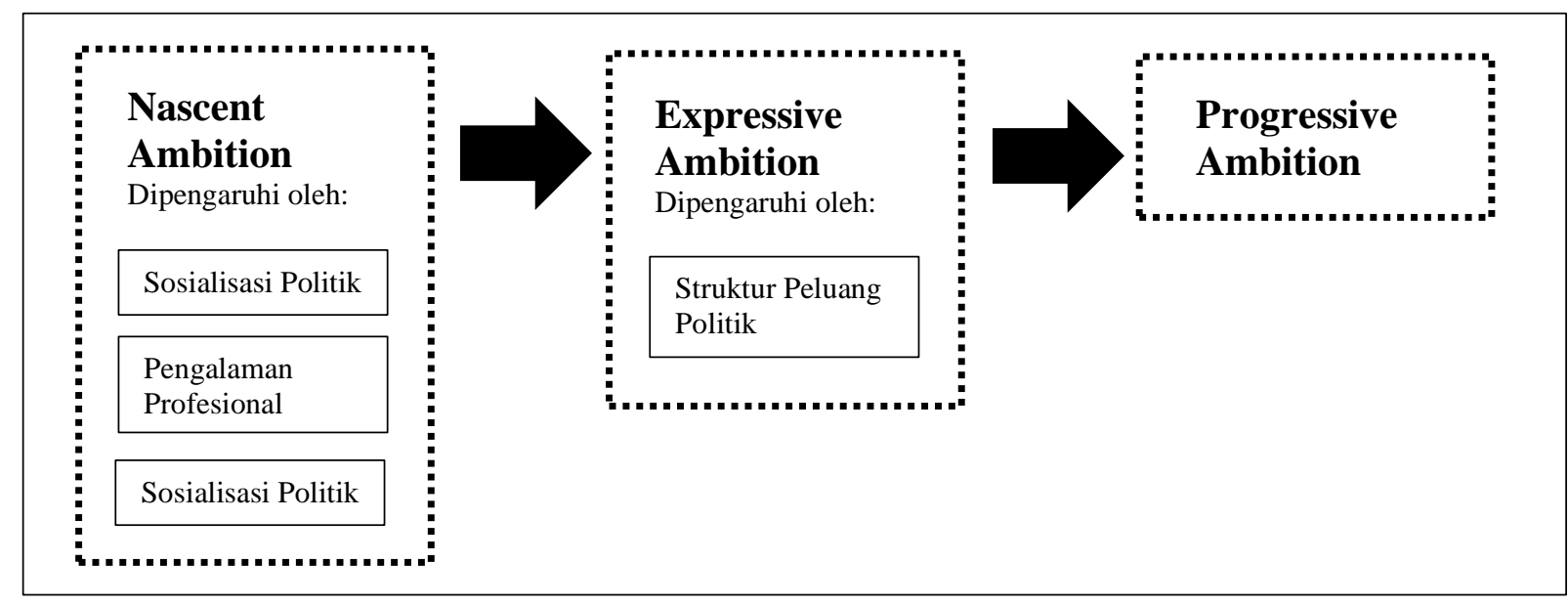

Gambar 1. Proses Ambisi Politik

Keikutsertaan Thae dan Ji dalam kontestasi pemilu di Korea Selatan menunjukkan adanya peningkatan ambisi (progresif) imigran Korea Utara untuk semakin berpartisipasi politik di Korea Selatan dengan mencalonkan diri ke jabatan yang lebih tinggi sebagai anggota Dewan Nasional. Ambisi progresif yang mereka dipengaruhi oleh adanya nascent ambition, yang terdiri dari sosialisasi politik dan pengalaman profesional sepanjang mereka berimigrasi ke Korea Selatan, serta isu politik yang sedang terjadi, sikap politik mereka terhadap isu yang ada, dan rekruitmen politik. Faktor-faktor inilah yang berperan mewujudkan nascent ambition Thae dan Ji untuk mempertimbangkan diri agar terlibat dalam politik elektoral di Korea Selatan. Struktur peluang politik (expressive ambition) di Korea Selatan tidak hanya memberikan kesempatan bagi imigran asal Korea Utara untuk berkontestasi di dalam Pemilu Legislatif Korea Selatan, namun juga menguatkan ambisi politik kedua imigran tersebut untuk mencalonkan diri. 


\section{Faktor sosialisasi politik dan pengalaman profesional}

Lawless mengemukakan bahwa studi mengenai kandidat dan pemangku jabatan tidak terlepas dari adanya kepentingan politik yang "diwariskan" yang menjadi keputusan yang perlu diperhitungkan bagi individu untuk memasuki politik dengan mengesampingkan latar belakang sosio-demografis atau kepribadian individu tersebut. Hipotesis yang ada selama ini mengemukakan bahwa kepentingan politik yang "diwariskan" ini umumnya merupakan hasil dari pengalaman di masa kecil (LeRoux \& Langer, 2019). Sebagaimana yang dirasakan oleh para imigran dari Korea Utara yang lainnya, Thae dan Ji juga mengalami sosialisasi politik pertama kali dari keluarga mereka yang berafiliasi dan bekerja langsung untuk negara tersebut. Mereka juga mengalami doktrinisasi selama mereka mengenyam pendidikan di sekolah, diajarkan mengenai monoloyalitas terhadap rezim Kim (The Freedom Collection, 2014), dan sebagainya. Selama bertahun-tahun sebagai warga negara Korea Utara, nilai-nilai itu yang membentuk orientasi politik mereka dan membuat mereka tetap bertahan pada sistem politik yang ada di Korea Utara.

Proses sosialisasi politik ini tidak berhenti sampai masa anak-anak saja. Di masa dewasa, kedekatan individu dengan masalah-masalah kebijakan serta kelompok sosial dan profesional yang berorientasi politik dapat memupuk ambisi politik dan menanamkan kualifikasi, serta rasa keberhasilan seseorang untuk mencalonkan diri sebagai pejabat politik. Pada tahun 1996, ketika Korea Utara mengalami masa-masa ekonomi yang sulit dan bencana kelaparan dimana-mana, Thae ditugaskan pertama kali di Denmark. Thae mengungkapkan ketika dirinya berada di Copenhagen, ia melihat dunia yang berbeda dengan apa yang ia pelajari mengenai dunia kapitalis selama menempuh pendidikan di Korea Utara. Sementara itu, di masa yang sama, Ji juga pertama kali terpaksa meninggalkan Korea Utara untuk pergi mencari makanan sampai ke Cina. Di Cina, ia dapat melihat secara langsung bagaimana kehidupan masyarakat setempat yang sudah lebih maju daripada negaranya.

Dari hasil wawancara bersama Thae di Ear to Asia Podcast episode 54 (Yong-ho, 2019) dan Ji (The Freedom Collection, 2014), penulis berargumen bahwa ketika para imigran Korea Utara memiliki kesempatan untuk keluar dari negara tersebut, mereka dihadapkan pada kondisi di negara baru yang mereka tempati itu berbeda dari apa yang mereka pernah pelajari di negara asalnya. Setelah mereka berhasil menginjakkan kaki di Korea Selatan, tentunya mereka mendapatkan sosialisasi politik yang baru oleh Pemerintah Korea Selatan melalui kebijakan Hanawon di mana mereka diedukasi mengenai sistem politik yang ada di Korea Selatan, sehingga mereka dapat lebih mudah berintegrasi dengan masyarakat setempat. Di kemudian hari, sosialisasi politik ini telah memperkuat political stance mereka melalui keterlibatan di dalam institusi, seperti tempat kerja, organisasi sukarela, dan institusi keagamaan dengan menyaksikan dan membandingkan sendiri apa yang terjadi di Korea Utara dan Korea Selatan. Proses sosialisasi politik ini meningkatkan persepsi Thae dan Ji tentang kualifikasi bagi mereka untuk mencalonkan diri, kemudian memunculkan ambisi yang baru (nascent ambition) untuk terjun ke dalam politik.

Selain sosialisasi politik, profesi individu dapat berfungsi sebagai gerbang menuju politik (Fox \& Lawless, 2005; Lawless, 2012). Individu yang memiliki pekerjaan bergengsi tinggi dan berupaya untuk meningkatkan puncak profesi mereka akan cenderung berpikir untuk memperoleh posisi kekuasaan politik atau menaiki tangga karier politik. Kondisi profesional individu tentunya mempengaruhi ambisi politik karena dari posisi profesi yang dimilikinya, seorang kandidat bisa dinilai pengetahuannya, kepercayaan diri, dan keterampilan yang memadai untuk bisa masuk dan berkembang di bidang politik. Usai meninggalkan jabatannya sebagai wakil duta besar Korea Utara di London dan membelot ke Korea Selatan, Thae dikabarkan sempat menerima pekerjaan di Institute for National Security Strategy, sebuah organisasi yang bekerja sama dengan National Intelligence Service-badan intelijen Korea Selatan-yang bertujuan untuk memberikan analisis mendalam dan rekomendasi kebijakan mengenai hubungan diplomasi, keamanan, ekonomi antar-Korea (Jong-Young \& Song, 2018). Berbekal pengalamannya sebagai warga negara Korea Utara yang selama ini banyak menarik atensi publik terhadap negara tertutup tersebut, Thae kerap hadir dalam berbagai interview untuk memberikan pandangannya terhadap rezim otoriter di Korea Utara yang sangat tertutup itu (Holt \& Smith, 2017). 
Lawless (dalam LeRoux \& Langer, 2019) juga menganalisis bahwa mereka yang memiliki karir sebelumnya sebagai aktivis politik paling tertarik untuk memasuki arena pemilihan. Selama menetap di Korea Selatan, Thae dan Ji juga merupakan aktivis masalah HAM di Korea Utara. Ji semakin terlibat menjadi aktivis hak asasi manusia untuk Korea Utara setelah ia melihat kejadian di mana banyak orang asing mendatangi Korea Utara dan mempromosikan aktivisme hak asasi manusia (The Freedom Collection, 2014). Melihat banyaknya orang luar yang berusaha meningkatkan taraf hidup masyarakat Korea Utara menjadi motivasi tersendiri bagi Ji untuk ikut terlibat. Pada tahun 2010, Ji memulai pengalamannya sebagai aktivis HAM dengan membentuk sebuah organisasi sosial bersama rekan-rekannya dari Korea Selatan. Organisasi yang dinamakan Now Action and Unity for Human Rights (NAUH) ini bertujuan untuk meningkatkan kesadaran mengenai Korea Utara dan mendorong aktivisme hak asasi manusia di Korea Utara. Organisasi ini juga berupaya mempersiapkan unifikasi di masa yang akan datang dengan cara menyelamatkan para pembelot Korea Utara yang melarikan diri ke Korea Selatan, mengampanyekan hak asasi manusia, memberikan pendidikan tentang demokrasi, dan kegiatan advokasi lainnya di komunitas internasional (Now Action \& Unity For Human Rights, n.d.).

Ji juga menginisiasikan berbagai proyek yang dikerahkan untuk membantu meningkatkan integrasi sosial antara Korea Utara dan Korea Selatan dengan menyiarkan informasi kepada para pemuda Korea Utara melalui saluran Radio Free Asia dan Far East Broadcasting. Kegiatan aktivisme politiknya ini rupanya telah menjadi sorotan publik, baik nasional maupun internasional. Pada tahun 2018-2019, kekuatan politik Ji semakin memuncak tatkala ia dilibatkan oleh Presiden Donald Trump dalam strateginya membangun tekanan internasional kepada pemimpin Korea Utara, Kim Jong Un, ke meja perundingan atas program senjata nuklirnya (Nakamura \& Min Joo, 2019). Bagaimana pun, Thae dan Ji berhasil meraih panggung politiknya sendiri dengan membuat diri mereka semakin dikenal publik serta membangun kepercayaan dan pemahaman sosial masyarakat terhadap mereka.

Dalam faktor ini juga, kita perlu melihat berbagai aspek yang memotivasi individu untuk terjun ke dalam politik elektoral, salah satu hal terpenting adalah ketersediaan sumber daya. Sumber daya yang dimaksud ini adalah waktu, uang, dan keterampilan. Lawless \& Fox (2005) menekankan bahwa ambisi material dan kesuksesan finansial juga menjadi pertimbangan seseorang untuk mencalonkan diri. Untuk kasus Thae Yong-ho, ia lahir di tengah keluarga yang memiliki status sosio-ekonomi yang memadai. Sepanjang perjalanan hidupnya, ia mendapatkan akses pendidikan, keterampilan, dan pekerjaan yang jauh lebih baik dibandingkan para pembelot Korea Utara lainnya. Tidak bisa dipungkiri, akses dan kapabilitas pendidikan yang Thae miliki tentunya menjadi faktor sumber daya yang mendorongnya untuk semakin terlibat dalam politik elektoral di Korea Selatan. Bahkan, Thae mengakui bahwa statusnya sebagai anggota elite dan diplomat Korea Utara telah memberikannya akses lebih kepada dunia luar mengenai kondisi kehidupan yang jauh lebih baik di bawah rezim yang demokratis dan menjunjung kebebasan, berbeda dengan kebanyakan penduduk Korea Utara yang tidak memiliki akses pengetahuan terhadap demokrasi dan terbelenggu di dalam rezim otoriter keluarga Kim.

Berbeda nasib dengan Thae, Ji Seong-ho bermigrasi ke Selatan untuk mendapatkan kehidupan yang lebih layak. Setelah membelot, ia mendapatkan kesempatan berkuliah ilmu hukum di Universitas Dongguk, salah satu universitas prestisius di Seoul. Tidak bisa dipungkiri, tingkat pendidikan juga menempatkan individu imigran, seperti Ji dan Thae, berada di strata sosial yang tinggi di Korea Selatan. Dengan pendidikan yang lebih baik, keduanya memiliki akses pengetahuan mengenai sistem elektoral dan politik di Korea Selatan seperti apa. Ini membuat mereka lebih mudah berkontribusi banyak dalam perpolitikan Korea Selatan dibandingkan imigran Korea Utara lainnya karena sebanyak 70 80\% para imigran Korea Utara yang datang ke Korea Selatan diisi oleh para perempuan yang melarikan diri untuk mencari kehidupan ekonomi yang lebih layak, sehingga mereka cenderung bersikap apolitis disebabkan kurangnya pengetahuan politik mengingat tingkat pendidikan dan peran perempuan yang relatif rendah serta terbatas dalam masyarakat Korea Utara (Jeong \& Kim, 2016). 


\section{Faktor isu politik, sikap politik, dan rekruitmen politik}

Salah satu faktor utama yang diduga mampu meningkatkan kecenderungan individu untuk berpartisipasi secara politik adalah minat isu individu tersebut (Lawless, 2012; LeRoux \& Langer, 2019). Bahkan, Verba et. Al (dalam LeRoux \& Langer, 2019) menemukan bahwa individu yang lebih memungkinkan untuk berpartisipasi dalam proses politik adalah mereka yang memiliki kepentingan pribadi dalam kebijakan pemerintah atau sangat peduli tentang masalah politik. Pada tahun 2019, terjadi sebuah kasus dua nelayan Korea Utara tertangkap berada di perairan Korea Selatan sedang berusaha untuk membelot diserahkan kembali oleh militer Korea Selatan ke otoritas Korea Utara (York, 2020). Kejadian seperti ini belum pernah terjadi sebelumnya, terlebih pada masa pemerintahan Presiden Park Geun-hye yang lebih terbuka pada kedatangan imigran Korea Utara di Korea Selatan. Keputusan Moon Jae-in untuk merepatriasi kedua nelayan Korea Utara tentu saja mengecewakan bagi para imigran Korea Utara lainnya yang menilai bahwa tindakan tersebut melanggar hak asasi manusia dan tidak demokratis.

Chung-in (2019) menjabarkan tiga prinsip Presiden Moon dalam menginisiasi perdamaian di Semenanjung Korea. Pertama, adanya kebijakan yang mengutamakan perdamaian dan tidak melibatkan tindakan militer apapun untuk menghindari konflik dan ancaman. Kedua, adanya kebijakan "tanpa nuklir", sehingga ia menyatakan bahwa Korea Selatan tidak akan memiliki persenjataan nuklirnya sendiri agar dapat hidup berdampingan secara damai dengan Korea Utara dan menghindari kehancuran yang dapat terjadi. Ketiga, tidak akan mengupayakan perubahan rezim di Korea Utara ataupun memaksakan adanya penyatuan a la Korea Selatan. Ia percaya bahwa jika hal tersebut dilakukan dapat memancing permusuhan dengan Pyongyang dan merusak kepercayaan yang telah dibangun. Tidak hanya itu, Presiden Moon juga mengeluarkan kebijakan mengenai hubungan di Semenanjung Korea yang membawa tiga nilai penting dalam upaya untuk menjalin hubungan dengan Korea Utara, yaitu perdamaian, rasa saling menghormati, dan keterbukaan. Melalui ketiga nilai tersebut, Moon mengeluarkan empat strategi pendekatan sebagai langkah komprehensif bagi Korea Selatan. Pertama, pemerintah Korea Selatan berusaha menghilangkan ancaman keamanan nuklir Korea Utara dengan cara membentuk rezim perdamaian di Semenanjung Korea dan memfasilitasi peningkatan hubungan antara Korea Utara dan komunitas internasional. Kedua, menangani masalah hubungan antar-korea dan ancaman nuklir Korea Utara secara bersamaan dengan membangun saluran untuk dialog dan kerjasama antar-Korea, serta memfasilitasi pembicaraan multilateral terkait penyelesaian masalah nuklir. Ketiga, memastikan adanya keberlanjutan melalui pelembagaan dengan memberlakukan perjanjian antar-Korea menjadi undang-undang. Keempat, membangun komunitas antar-Korea dengan memperluas berbagai pertukaran antar-Korea sebagai bagian dari proses memmpromosikan koeksistensi dan kemakmuran bersama kedua Korea.

Ambisi politik Thae dan Ji terbentuk dari adanya rasa keinginan untuk menangani masalahmasalah lokal tersebut akibat ketidakpuasan terhadap kebijakan, strategi, dan prinsip luar negeri yang dimiliki Presiden Moon dalam mengatasi hubungan dengan Korea Utara. Hal ini dikritisi dan dinilai oleh Thae dan Ji kurang mampu mendorong tindakan denuklirisasi Korea Utara dan memperlambat adaya perjanjian perdamaian formal antar-Korea (Hyung-Jin, 2020). Thae juga sempat mengecam diplomasi pemerintahan yang dilakukan oleh Presiden Moon. Terlebih, Pemerintah Seoul dikabarkan berupaya mengejar adanya program "pariwisata independen" dengan Korea Utara, sehingga hal tersebut dikritik Thae bahwa pemerintahan yang berkuasa saat ini nampaknya "mengakui" rezim Kim Jong Un sebagai sebuah negara (Jeongmin, 2020).

Martin dan Jeong (2020) menyebutkan bahwa Pemerintahan Moon juga mendapatkan kecaman dari kelompok aktivis hak asasi manusia dan politisi yang dinilai terlalu memprioritaskan hubungan antar-Korea daripada pelanggaran hak asasi manusia yang dilakukan oleh rezim Kim kepada warga negara Korea Utara, bahkan pemerintahan Moon juga menolak menjadi sponsor dalam agenda resolusi Perserikatan Bangsa-Bangsa (PBB) yang membahas mengenai masalah hak asasi manusia di Korea Utara. Sikap dan kebijakan yang dikeluarkan oleh Presiden Moon dalam mengatasi hubungan dengan Korea Utara dinilai mengecewakan, sehingga Ji berkeinginan untuk semakin membantu imigran Korea Utara lainnya yang berusaha untuk melarikan diri. Keinginan tersebut telah mendorongnya untuk ikut serta mencalonkan diri ke 
dalam Pemilihan Legislatif 2020 agar ia semakin dapat berkontribusi untuk memberlakukan undang-undang yang membantu meningkatkan situasi hak asasi manusia di Korea Utara, serta menyusun kebijakan yang sekiranya mendukung para pembelot sepertinya (Byung-joon, 2020).

Ketidakpercayaan Thae dan Ji terhadap cara Pemerintah Korea Selatan dibawah kepemimpinan Presiden Moon Jae-in dalam memperlakukan para imigran Korea Utara yang melarikan diri ke Korea Selatan menempatkan sikap politis mereka. Sikap tersebut mengharuskan keduanya memenuhi syarat dalam sistem politik, yaitu dengan terlibat dan terafilisasi partai politik yang dapat mendukung ruang gerak mereka. Sebagai salah satu institusi politik, keberadaan partai-partai politik dapat memainkan peran dalam menumbuhkan minat untuk mencalonkan diri. Partai politik dianggap menjadi "penjaga gerbang" dalam pemilu yang mampu memnafaatkan partisan mereka untuk dicalonkan sebagai kandidat. Penulis berargumen bahwa pihak oposisi konservatif di Korea Selatan memanfaatkan suara kemarahan dan kekecewaan para imigran Korea Utara atas kebijakan luar negeri yang diterapkan oleh Presiden Moon terhadap Korea Utara. Mengingat kebijakan tersebut banyak merugikan para imigran Korea Utara, politisi-politisi konservatif mulai berbicara atas nama mereka. Tidak hanya itu, partaipartai konservatif juga merekrut Thae dan Ji, serta mengusungkan kedua tokoh tersebut untuk berkontestasi di Pemilian Legislatif 2020.

Jumin (2020) menyebutkan bahwa politisi konservatif pada akhirnya mendapatkan keuntungan dari memberikan suara kepada para pembelot tersebut dalam koalisi mereka. Memang perlu diakui, rekruitmen politik yang dilakukan pihak konservatif kepada imigran Korea Utara ini dinilai menjadi sebuah langkah yang progresif mengingat kelompok konservatif tradisional menganggap Korea Utara adalah ancaman dengan ideologi komunismenya. Akan tetapi, di masa kini, daya tarik yang didasarkan pada kemurnian ideologis menjadi kurang efektif untuk digencarkan. Kini, politisi-politisi konservatif di Korea Selatan membutuhkan aktor politik baru yang berasal dari Korea Utara dan isu baru yang mereka fokuskan, yaitu mengenai masalah hak asasi manusia. Perspektif mereka mengenai Korea Utara telah bergeser, bukan lagi menyinggung bahwa rezim Korea Utara tidak dapat dipercaya karena komunis, melainkan karena negara tersebut otoriter (Jumin, 2020). Terlebih, populasi imigran Korea Utara di Korea Selatan sendiri telah mencapai lebih dari 30.000 penduduk. Tentunya, dengan mengusung kedua tokoh yang berlatarbelakang yang sama, partai konservatif cenderung mudah untuk mendapatkan dukungan suara telak dari imigran Korea Utara lainnya.

Lantas, mengapa partai konservatif tidak memilih mengusung imigran Korea Utara yang lain, selain Thae dan Ji? De Rooij (2012) menyebutkan bahwa imigran cenderung sulit dijangkau oleh partai-partai politik, karena mobilitas tempat tinggal mereka, kurangnya catatan partisipasi sebelumnya, dan potensi kendala bahasa mendorong rendahnya keterlibatan politik imigran. Pihak konservatif menilai bahwa Thae dan Ji adalah sosok yang tepat untuk merepresentasikan kepentingan Korea Utara berdasarkan pengalaman dan kemampuan yang mereka miliki. Begitu pun sebaliknya, Thae dan Ji juga memilih untuk bergabung bersama partai-partai konservatif yang tentunya memiliki persamaan visi dan misi dengan mereka dalam merespon dan mengkritisi kebijakan luar negeri Pemerintahan Moon terhadap Korea Utara dan hubungan di Semenanjung Korea. Secara luas, dukungan umum partai-partai konservatif untuk memasuki politik elektoral dapat memberikan rasa legitimasi yang dibutuhkan bagi Thae dan Ji yang mencalonkan diri, sehingga mereka mampu lebih mudah menilai lingkungan pemilihan sebagaimana Lawless (2012) menyebutkan bahwa orang-orang yang menerima dorongan untuk mencalonkan diri dari para aktor politik lebih mungkin untuk berpikir serius untuk ikut ke dalam pencalonan. Akan tetapi, terlepas dari itu semua, penulis sepakat dengan pendapat Ok-Jeong dan Sil-Kim (2016) bahwa sikap politik para pembelot ini menyerupai imigran lainnya dari negara-negara otoriter ataupun sosialis yang cenderung mengadopsi perspektif konservatif tentang masalah politik.

\section{Struktur peluang politik}

Faktor-faktor sebelumnya telah berperan untuk membentuk nascent ambition Thae dan Ji sebagai imigran untuk mempertimbangkan pencalonan diri ke politik elektoral. Kemudian, ambisi politik tersebut menguat dengan adanya struktur politik (expressive ambition) yang semakin 
memberikan keduanya peluang untuk maju sebagai kandidat di dalam Pemilihan Legislatif Korea Selatan tahun 2020. Sebagaimana yang tertuang dalam UU Pemilihan Umum di Korea Selatan pasal 16, ayat (2) menyatakan bahwa warga negara Korea yang berusia 25 tahun atau lebih diizinkan untuk mencalonkan diri ke dalam pemilihan untuk Majelis Nasional (Jong-Woo, 2010: 3). Kelayakan elektoral ini memberikan hak bagi warga Korea untuk mewakili kepentingan mereka, sehingga orang asing tidak bisa mendapatkan hak untuk terlibat di dalam elektoral. Namun, penting untuk mengetahui jika UU Kewarganegaraan di Korea Selatan menetapkan aturan bahwa warga negara Korea Utara, sejak lahir, secara otomatis telah menjadi warga negara Korea Selatan (Wolman, 2014: 8-9). Ini menyimpulkan bahwa warga negara Korea Utara yang membelot ke Korea Selatan otomatis diterima menjadi warga negara oleh pejabat pemerintah setempat dan diakui secara hukum. Oleh karena itu, status kewarganegaraan Thae Yong-ho dan Ji Seong-ho sudah dapat dipastikan merupakan warga negara Korea Selatan yang sudah berusia layak, sehingga mereka diizinkan mencalonkan diri ke dalam pemilihan untuk Majelis Nasional di Korea Selatan.

Selain itu, Pemilihan Legislatif 2020 menerapkan sistem elektoral yang baru dicanangkan oleh pemerintahan Presiden Moon Jae-In. UU Reformasi Pemilihan ini menurunkan usia pemilih dan juga memperkenalkan sistem perwakilan proporsional yang baru diterapkan di Korea Selatan. Dalam pemilu legislatif kali ini, sebanyak 300 anggota Majelis Nasional terpilih yang terbagi menjadi dua sistem, yaitu (i) sebanyak 253 anggota terpilih berdasarkan sistem konstituen first-past-the-post dan (ii) sebanyak 47 anggota lainnya terpilih berdasarkan sistem daftar proporsional partai. Sehingga, pemungutan suara di Korea Selatan tidak hanya memungkinkan pemilih untuk memilih calon untuk distrik masing-masing, tetapi juga untuk memilih partai politik pilihan mereka (Stangarone, 2020)

Dengan sistem konsituten first-past-the-post, Thae berhasil mencalonkan diri sebagai kandidat untuk distrik Gangnam di Dewan Nasional. Distrik Gangnam terkenal sebagai distrik terkaya dan menjadi area politik konservatif di Korea Selatan (Bae \& Joo, 2020), sehingga komposisi partisan di daerah Gangnam ini semakin memperbesar peluang Thae untuk terlibat ke dalam politik elektoral di negara tersebut. Melalui sistem ini, Thae berhasil memenangkan bangku di parlemen dengan total suara sebesar $58,4 \%$ dan ini menjadikannya sebagai pembelot Korea Utara pertama yang berhasil memenangkan bangku parlementer di Korea Selatan dengan sistem konstituen first-past-the-post (Bicker, 2020). Sementara itu, kebijakan reformasi pemilu Korea Selatan memang didesain untuk meningkatkan peluang bagi partai politik kecil untuk juga mendapatkan kursi perwakilan yang proporsional (Stangarone, 2020). Hal ini tentu saja memberikan peluang Ji untuk mencalonkan diri ke dalam politik elektoral melalui Partai Future Korea Party, salah satu partai kecil berhaluan konservatif yang menjadi partai satelit dari Partai Unified Future Party. Pada akhirnya, suara keseluruhan yang didapatkan FKP ini cukup untuk memberikan Ji kursi di Majelis Nasional.

\section{Simpulan dan saran}

Kemenangan Thae Yong-ho dan Ji Seong-ho, sebagai imigran Korea Utara yang membelot ke Korea Selatan, dalam Pemilu Legislatif di Korea Selatan tahun 2020 silam menjadi momentum penting dalam perpolitikan di Korea Selatan. Keterlibatan mereka di dalam pemilu tersebut didorong oleh ambisi politik yang baru muncul (nascent ambition) dan juga struktur peluang politik di Korea Selatan. Nascent ambition keduanya dapat dilihat dari proses sosialisasi politik, pengalaman profesi, status sosial-ekonomi yang dimiliki oleh Thae dan Ji. Kemudian, isu dan sikap politik keduanya terhadap kebijakan Presiden Moon Jae-In mengenai hubungan di Semenanjung Korea dan tindakan Pemerintah Korea Selatan merepatriasi kedua nelayan Korea Utara juga semakin mendorong ambisi politik mereka untuk dapat merepresentasikan suara imigran Korut di sana. Terakhir, kita juga dapat melihat bagaimana kebijakan pemilihan umum dan UU Kewarganegaraan di Korea Selatan yang memberikan peluang bagi Thae dan Ji untuk terjun ke dalam politik elektoral di Korea Selatan. Untuk penelitian lebih lanjut, penulis menyarankan pembahasan mengenai implementasi dan evaluasi kinerja Thae dan Ji dalam mengadvokasi kepentingan imigran Korea Utara di Korea Selatan selama mereka menjabat. 
Penelitian lebih empiris dengan wawancara mendalam terhadap tokoh imigran yang berkompetisi ataupun mundur dalam kompetisi menarik untuk dilakukan. Selain akan mendapatkan pemahaman yang lebih mendalam kenapa mereka maju, mundur, ataupun tidak maju, informasi terkait hambatan tertentu yang lebih spesifik mungkin akan diperoleh. Penelitian dengan survey dan responden jumlah besar juga akan menarik untuk membuat generalisasi lebih luas.

\section{Daftar Rujukan}

Bae, Y., \& Joo, Y. M. (2020). The Making of Gangnam: Social Construction and Identity of Urban Place in South Korea. Urban Affairs Review, 56(3), 726-757. https://doi.org/10.1177/1078087419827645

Bicker, L. (2020). North Korean defector becomes first to win South Korea parliamentary seat. BBC News. Diambil tanggal 6 Maret 2021 dari https://www.bbc.com/news/world-asia52305447.

Byung-joon, K. (2020). (Yonhap Feature) N. Korean defectors eye politics as weapon to make voice heard. Yonhap News Agency. Diambil tanggal 6 Maret 2021 dari https://en.yna.co.kr/view/AEN20200318007600325.

Chubb, D. (2010). Defector politics: The political activism of North Korean Saetomin. Critique Internationale, 49(4), 37-51. https://doi.org/10.3917/crii.049.0037

Chung-in, M. (2019). President Moon Jae In's and the Korean Peace Initiative. Global Asia, 14(2), pp. 10-17.

Creswell, J. W. (2007). Research Design: Qualitative, Quantitative and Mixed Method Aproaches. SAGE Publications. https://doi.org/10.4135/9781849208956

Fifield, A. (2018). The incredible story of the North Korean escapee at the State of the Union. The Washington Post. Diambil tanggal 6 Maret 2021 dari https://www.washingtonpost.com/news/worldviews/wp/2018/01/30/the-incrediblestory-of-the-north-korean-escapee-at-the-state-of-the-union/.

Fox, R. L., \& Lawless, J. L. (2005). To run or not to run for office: Explaining nascent political ambition. American Journal of Political Science, 49(3), 642-659. https://doi.org/10.1111/j.1540-5907.2005.00147.x

Holt, L., \& Smith, A. (2017). North Korean Defector Tells Lester Holt "World Should Be Ready." NBC News. Diambil tanggal 6 Maret 2021 dari https://www.nbcnews.com/news/world/northkorean-defector-tells-lester-holt-world-should-be-ready-n741901.

Huddleston, T. (2017). Migrant political participation : a review of policies and integration results in the OSCE region. Officer of Democratic Institutions and Human Right. Diambil tanggal 6 Maret 2021 dari https://www.osce.org/odihr/367936?download=true.

Hyung-Jin, K. (2020). High-level North defector to run for South Korean parliament. Associated Press News. Diambil tanggal 6 Maret 2021 dari https://apnews.com/article/a2a93acf7fa6f3040aa0f05fec7e838c.

Jeong, H. O., \& Kim, Y. S. (2016). North Korean women defectors in South Korea and their political participation. International Journal of Intercultural Relations, 55, 20-31. https://doi.org/10.1016/j.ijintrel.2016.07.008

Jeongmin, K. (2020). Former North Korean diplomat clinches historic win in South Korean election. NK News. Diambil tanggal 6 Maret 2021 dari https://www.nknews.org/2020/04/formernorth-korean-diplomat-clinches-historic-win-in-south-korean-election.

Jong-Woo, L. (2010). Political Participation of Immigrants in Korea. National Election Commission. Jong-Young, L., \& Song, L. (2018). High-profile defector quits state-sponsored job. Korea JoongAng Daily. Diambil tanggal 6 Maret 2021 dari https://koreajoongangdaily.joins.com/news/article/article.aspx?aid=3048523.

Jumin, L. (2020). Northern Wind: Thae Yong-ho's ambitions could transform South Korean politics. NK News. Diambil tanggal 6 Maret 2021 dari https://www.nknews.org/2020/02/northernwind-thae-yong-hos-ambitions-could-transform-south-koreanpolitics/?t=1587013374710. 
Lawless, J. L. (2012). The Decision to Run for Office. In Becoming a Candidate: Political Ambition and the Decision to Run for Office (Issue June 2008, pp. 14-30). Cambridge University. https://doi.org/10.1017/cbo9780511806001.002

Lee, S. (2019). South Korea's Refugee Policies: National and Human Security Perspectives. In Human Security and Cross-Border Cooperation in East Asia (pp. 227-248). Springer International Publishing. https://doi.org/10.1007/978-3-319-95240-6

LeRoux, K., \& Langer, J. (2019). From Nonprofit Leader to Elected Official: Examining Political Ambition in the Nonprofit Sector. Nonprofit and Voluntary Sector Quarterly, 48(1), 208-226. https://doi.org/10.1177/0899764018807757

Martin, T. W., \& Jeong, A. (2020). Unhappy With South Korea's Stance on the North, Defectors Use Elections to Push a Tougher Line. The Wall Street Journal. Diambil tanggal 6 Maret 2021 dari https://www.wsj.com/articles/unhappy-with-south-koreas-stance-on-the-northdefectors-use-elections-to-push-a-tougher-line-11582066607.

Nakamura, D., \& Min Joo, K. (2019). State of the Union: He helped Trump confront North Korea. Now Ji Seong-ho wonders if human rights will be left behind. The Washington Post. Diambil tanggal 6 Maret 2021 dari https://www.washingtonpost.com/politics/he-helped-trump-confrontnorth-korea-now-ji-seong-ho-wonders-whether-human-rights-will-be-leftbehind/2019/02/03/b5bdbee2-257b-11e9-81fd-b7b05d5bed90_story.html.

Now Action \& Unity For Human Rights. (n.d.). About NAUH. NAUH. Diambil tanggal 6 Maret 2021 dari https://nauh.or.kr/eng/about/team/.

Stangarone, T. (2020). The North Korean Subplots in South Korea's National Assembly Elections. The Diplomat. Diambil tanggal 6 Maret 2021 dari https://thediplomat.com/2020/04/thenorth-korean-subplots-in-south-koreas-national-assembly-elections/.

The Freedom Collection. (2020). Freedom Collection » Interviews» Ji Seong-ho. George W. Bush Institute. Diambil tanggal 6 Maret 2021 dari http://www.freedomcollection.org/interviews/ji_seong-ho/.

Wolman, A. (2014). The South Korean Citizenship of North Korean Escapees in Law and Practice. City 4(2), 225-253. University of London.

Yong-ho, T. (2019). Ear to Asia podcast (pp. 1-14). The University Melbourne.

York, R. (2020). What Thae Yong Ho offers South Korea's conservatives. Daily NK. Diambil tanggal 6 Maret 2021 dari https://www.dailynk.com/english/what-thae-yong-ho-offers-southkoreas-conservatives. 